\section{Summer School in Inorganic Micro-Chemistry}

Although the advantages of small-scale methods of analysis have led to provision in various British universities and technical colleges for a certain amount of instruction in micro-techniques, it is believed that refresher courses for chemists who have not had recent contact with micro-methods would be of value (see also Nature, 156, 588; 1945). Modern micromethods are essential for attacking certain analytical problems, and in addition selected semi-micro and micro-methods offer advantages over more conventional methods in the teaching of practical chemistry to undergraduates. To provide practical experience in modern small-scale techniques, a summer school has been arranged at Queen's University, Belfast, during June 23-July 5. This course is planned to provide about seventy-five hours practical work. Particulars can be obtained from the secretary of the University.

\section{Summer Course on Rheology}

A sHort summer course on rheology will be given at the Polytechnic, Regent Street, London, W.1, during July 28-31. It is specially designed for those engaged on rheological problems in industry, and the lectures will deal with general rheology, as well as with certain special applications. The lecturers will include Dr. G. W. Scott Blair and Dr. L. R. G. Treloar. Particulars may be obtained from Dr. J. Topping, Polytechnic, Regent Street, London, W.I.

\section{Place of Universities in the Community}

THE Division for Social and International Relations of Science of the British Association has arranged a conference on "The Place of Universities in the Community", to be held in the University of Manchester on May 10. The speakers will include: Lord Simon of Wythenshawe, Sir Henry Dale, Prof. J. D. Bernal, Prof. P. M. S. Blackett and Prof. M. Polanyi. Opportunity will be provided for other contributions to the discussion. Admission will be free, without tickets. Further particulars can be obtained from the secretary of the British Association.

\section{Travelling Atomic Energy Exhibition}

A TRAVELCING train exhibition is being organised by the Atomic Scientists' Association with the cooperation of the Ministry of Supply to illustrate the facts about atomic energy and its industrial applications in a simple and attractive manner. 'The train will visit fifty-five of the principal towns of Great Britain and take a year to complete the course. The information will be conveyed by charts, diagrams and photographs. It is also planned to show some simple experiments as well. At the various stopping places it is hoped to organise 'Atomic Weeks', which will include public discussions, in order to focus attention on the significance of the industrial revolution which will be brought about by the harnessing of atomic energy.

\section{Comets}

Comes Grigg-Skjellerup (1947a). E. L. Johnson, Johannesburg, recovered this comet on March 11, about $2^{\circ}$ from the place predicted by F. R. Cripps in the "Handbook of the British Astronomical Association, 1947". Its magnitude was 11, but it will be a little brighter in May. An ephemeris is given below.

\begin{tabular}{|c|c|c|c|c|}
\hline 1947 & $0^{\text {h }}$ R.A. & Dec. & $r$ & $\rho$ \\
\hline May $\begin{array}{r}7 \\
15 \\
23\end{array}$ & $\begin{array}{c}22 \mathrm{~h} 38.1 \mathrm{~m} \\
24 \cdot 5 \\
16.6\end{array}$ & $\begin{array}{r}+17^{\circ} 20^{\circ} \\
21 \quad 29 \\
24 \quad 29\end{array}$ & 0.948 & $0 \cdot 357$ \\
\hline 31 & $10 \cdot 4$ & +2647 & $1 \cdot 071$ & 0.467 \\
\hline
\end{tabular}

Two other comets have been discovered but are faint objects. Ephemerides are given for the month of May.

Comet Jones (1946h).

\begin{tabular}{|c|c|c|c|c|c|}
\hline $\begin{array}{r}1947 \\
\text { May } \\
15 \\
23 \\
31 \\
31\end{array}$ & $\begin{array}{c}\text { Oh R.A. } \\
20 \mathrm{~h} 08 \cdot 6 \mathrm{~m} \\
07 \cdot 2 \\
\\
04 \cdot 0 \\
1959 \cdot 1\end{array}$ & $\begin{array}{r}\text { Dec. } \\
+34^{\circ} 26^{\prime} \\
3658 \\
3917 \\
+4120\end{array}$ & $3 \cdot 208$ & $2 \cdot 870$ & $\mathrm{Ma}$ \\
\hline Com & Bester ( & $6 k)$ & & & \\
\hline $\begin{array}{r}1947 \\
\text { May } 7 \\
15 \\
23 \\
31\end{array}$ & $\begin{array}{c}\text { 0h R.A. } \\
\text { 1h } 43.7 \mathrm{~m} \\
46.8 \\
49.6 \\
51.9\end{array}$ & $\begin{array}{r}\text { Dec. } \\
+25^{\circ} 35^{\circ} \\
2759 \\
3027 \\
+3259\end{array}$ & $2 \cdot 631$ & $3 \cdot 521$ & \\
\hline
\end{tabular}

\section{Announcements}

Prof. P. M. S. BLACKETT, Langworthy professor of physics in the University of Manchester, will deliver a lecture on "The Magnetic Field of Massive Rotating Bodies" at a meeting of the Royal Society on May 15 at 4.30 p.m.

Prof. E. D. Adrian, professor of physiology in the University of Cambridge, will deliver the Alexander Pedler Lecture under the auspices of the British Association on May 14 at 5.30 p.m. The Lecture will be given in the Royal Institution, and Prof. Adrian will speak on "The Sense of Smell". Tickets are available on application to the secretary of the British Association.

IN connexion with the Pasteur Exhibition at the Science Museum, two public lectures will be given in the lecture theatre of the Museum on Pasteur and his work : Prof. J. D. Bernal will speak on "Pasteur, the Crystallographer" on May 14 at 5 p.m. ; Dr. E. Chain on "Pasteur, the Biochemist" on May 19, also at 5 p.m.

Messas. Kodak Lto., Wéaldstone, Harrow, Middlesex, have arranged an exhibition of applied photography to be held at Australia House, Strand, London, during May 7-16, 10 a.m.-5.30 p.m. (except May 10 and 11). The exhibition will be opened by Prof. E. N. da C. Andrade on May 6 at 11 a.m.

Dr. F. D. Ommanney has been appointed by the Colonial Office to be marine biologist, MauritiusSeychelles Fishery Survey.

THe Twelfth International Congress of Psychology, postponed from 1940, will be held in Edinburgh during July 23-29, 1948. Prof. James Drever is president of the Committee of Organisation, and Prof. Godfrey Thomson, Moray House, Edinburgh, 8, is general secretary. It will facilitate arrangements if those likely to attend will communicate with the general secretary.

Ar the annual general meeting of the Gas Research Board, Viscount Falmouth was re-elected president for 1947-48, and Dr. Harold Hollings, controller of research of the Gas Light and Coke Co., has been appointed chairman in succession to Dr. E. V. Evans, who has resigned.

Eirratum. In the communication "Plasma Cellular Reaction and its Relation to the Formation of Antibodies in vitro" in Nature of April 12, p. 499, the abbreviation 'pcs' used by the author in the heading of col. 6 of Table 1 was wrongly interpreted as 'plasma cells'; it should read 'pieces'. 